\title{
Thieme E-Journals
}

Flere NFUD-medlemmer har stilt spørsmål om elektronisk tilgang også til eldre artikler i Ultraschall in der Medizin fra 1980 og Ultraschall in der Medizin - European Journal of Ultrasound fra 2004.

NFUD medlemskap inkluderer abonnement på årlig 6 utgaver av Ultraschall in der Medizin - European Journal of Ultrasound. Tidsskriftet kommer i posten i papirutgave, men kan samtidig også leses og søkes elektronisk via Thieme E-Journals https://www.thieme-connect.com/ejournals/home.html?letter=U.

Her må en registrere seg (Fig. 1). Klikk på „Register now“ og velg fanen „Registration for Individual Subscribers“ og følg instruksjonene . Vil en oppgi abonnementsnummeret, finnes det på adressearket som er vedlagt i plastposen av Journalens papirutgave (Fig. 2)

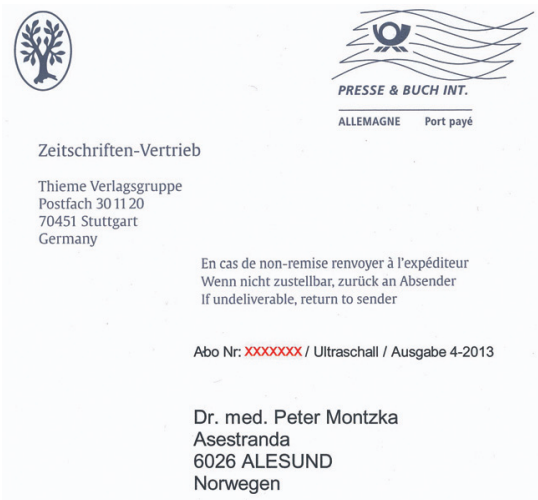

Fig. 2 Abonnementsnummer

Men også uten abonnementsnummer bare hopp over feltet - fullføres registreringen og en har umiddelbart tilgang til aktuelle årgangen. Full tilgang etableres i løpet av maks 1 uke, når Thieme har verifisert abonnementenes opplysninger. En får da opp Ultraschall in der Medizin tilbake til 1. utgave i 1980 og kan i „Search“ feltet søke gjennom alle utgaver i enten
99. https//www.thieme-connect.com/ejournals/home.html?letter=U

Edit View Favorites Tools Help

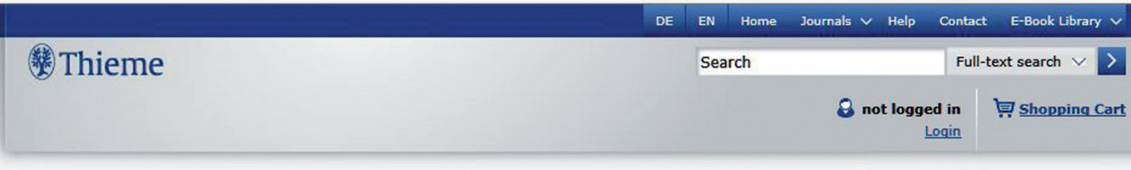

\section{Welcome to Thieme E-Journals}

Thieme's Online Journal Services provides you with the access to about 150 STM and Professional journals published by Thieme Publishing Group.
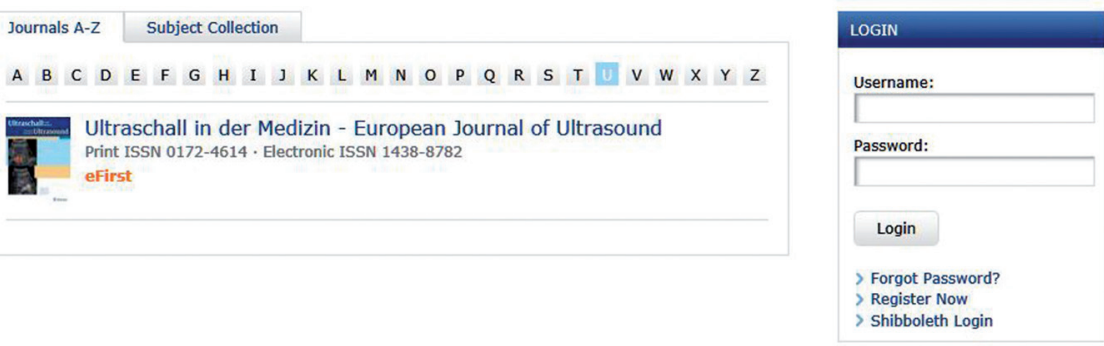

Fig. 1 Velkomstside Thieme E-Journals

full tekst, autor, tittel, DOI (Document Object Identifier) eller metadata modus. Artiklene kan stort sett åpnes i enten HTML

eller PDF format, mens PDF delvis kan være utilgjengelig (Fig. 3)

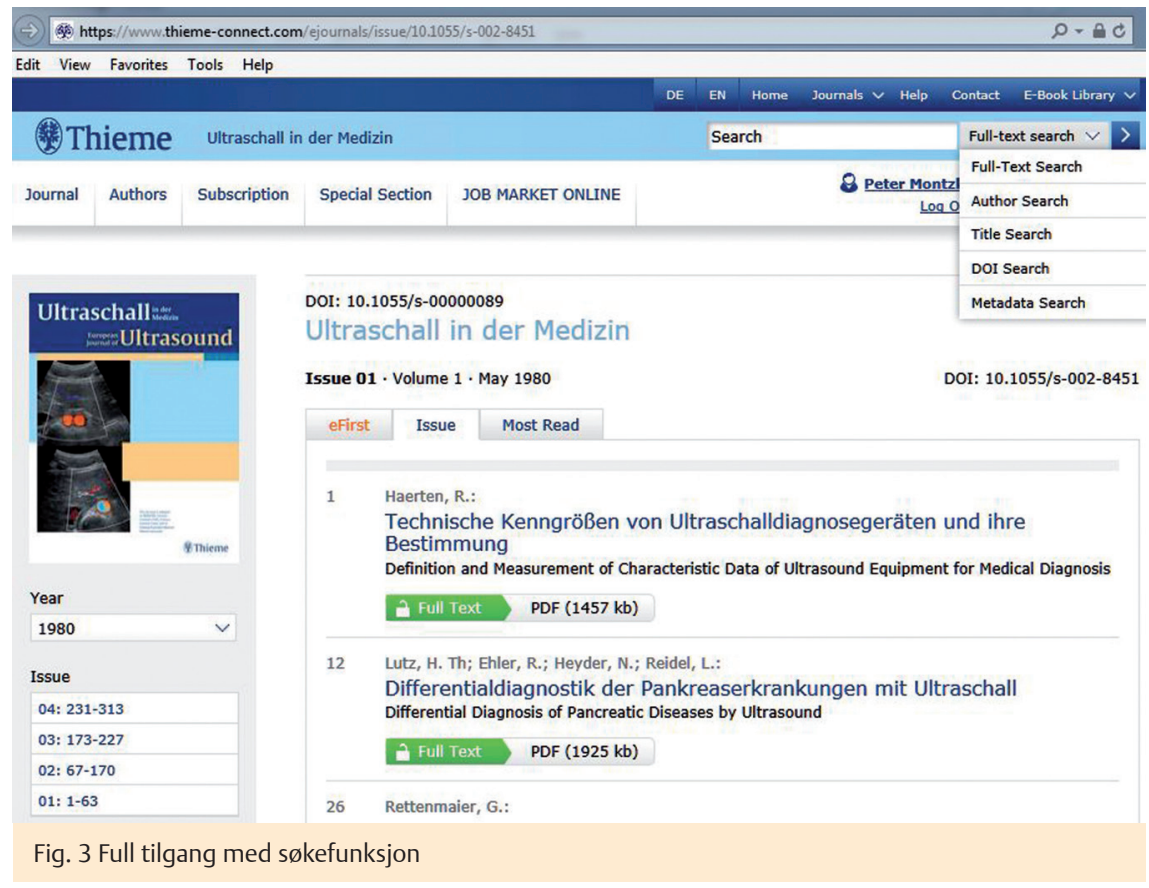

